\title{
Får karsyke god nok behandling?
}

Pasienter med perifer karsykdom har 2-3 ganger høyere risiko enn normalbefolkning med samme kjønn og alder for død, hjerteinfarkt eller hjerneslag (1). Prevalensen av slik sykdom hos voksne er 3-10\% - det angår mange mennesker $(1,2)$. Ved nyoppdaget sykdom har man en gyllen anledning til å initiere eller intensivere sekundærprofylakse hos pasienten. Sekundær profylakse er ikke bare viktig for å hindre videreutvikling av den perifere karsykdommen, det kan også redusere forekomst eller forverring av hjerte- og karsykdom og risiko for iskemisk hjerneslag. Det foreligger internasjonale retningslinjer med anbefalinger for hva slags oppfølging og behandling disse pasientene bør få $(2,3)$. Retningslinjene er utarbeidet av et internasjonalt panel av eksperter, med høy grad av enighet. Anbefalingene går i korte trekk ut på livsstilsendring med røykestopp og økt fysisk aktivitet, streng blodsukkerregulering og kolesterolsenkende behandling med kost og statiner. Dertil kommer medikamentell behandling med blodplatehemmere, behandling av høyt blodtrykk, og ACE-hemmer til pasientene med høyest risiko. Er det allmennlegen eller karkirurgen som bør følge pasienten i et slikt løp?

Mange hevder at pasientene blir bedre fulgt opp hos karkirurgen som har dette som sitt spesialtfelt, mens andre argumenterer med at dette er en kronisk sykdom som krever livslang oppfølging, noe som gjør at pasientene bør følges opp av fastlegen sin (4). Noen mener pasienten blir mer motivert til å følge opp behandling de får hos spesialist. Andre mener at pasientene er best tjent med oppfølging i grupper med helsepedagogisk veiledning, for eksempel i regi av et lærings- og mestringssenter, for å få til røykeslutt og trening. Ofte vil flere tilnærminger være nødvendig for å få til en optimal sekundærprofylakse.

Hovedproblemet er at de etablerte retningslinjer ikke følges tilstrekkelig opp, verken hos fastlegen eller hos spesialisten, til tross for at pasienter med perifer karsykdom har generalisert karsykdom $(5,6)$. Pasientene får ikke i tilstrekkelig grad tilbud om trening og kurs for røykestopp, og behandlingsmålene nås ikke ved den medikamentelle behandlingen $(5,6)$. Hva er det som gjør at retningslinjene ikke følges til tross for at det hersker en samstemt enighet om at disse pasientene har stor gevinst av å gjennomføre slik sekundærprofylaktisk behandling?

Alt fra mangel på kunnskap om innholdet i retningslinjene til manglende organisatorisk støtte, for lite avsatt tid og manglende vektlegging fra overordnede kan virke inn $(7,8)$. Det kan være viktig med hyppige påminnelser om retningslinjene $\mathrm{i}$ interne rutiner, kurs og internundervisning $(7,8)$. Måling av i hvor stor grad retningslinjene følges, med tilbakemelding til miljøet som grunnlag for diskusjon om endring i interne rutiner, kan også bidra positivt (9).

I Tidsskriftet nr. 20-22/2009 presenteres en temaserie om karsykdom og om utredning, behandling og oppfølging av pasienter med perifer karsykdom. Det kan være en begynnelse. Vi trenger en bevisstgjøring om denne pasientgruppens egenart, om pasientenes behov for og gevinster av sekundærprofylakse. Vi vet verken nok om hva som er mest effektivt for å motivere pasientene til å følge behandlingen, eller hvordan helsepersonell mest effektivt kan organisere slik sekundærprofylaktisk behandling. God forskning om disse vanskelige spørsmålene er fremdeles mangelvare. Mens vi venter på det, kan vi la oss inspirere av gode eksempler: Ved Rigshospitalet i Danmark er det opprettet en egen sekundærprofylaktisk poliklinikk, der pasienten ved hvert besøk făr med seg utskrift av sine resultater med hensyn til røyking, gangdistanse, blodtrykk, kolesterol og $\mathrm{HbA}_{1 \mathrm{c}}$ /blodsukker. Denne tilnærmingen baserer seg på at det er pasientens egen motivasjon og forståelse av sin sykdom som er det avgjørende for en vellykket sekundærprofylakse. Dette er også bakgrunnen for at norske karkirurger har laget en egen nettside med informasjon om karsykdommer, der pasientene selv kan se de råd de bør følge (10).

Jeg håper Tidsskriftets serie om den karkirurgiske pasient vil inspirere alle som har ansvar for slike pasienter til å følge dem opp med sekundærprofylaktiske tiltak i henhold til de kunnskapsbaserte retningslinjene. Dersom dette også kan sparke i gang en debatt, prinsipielt og lokalt, om hvem som skal ha ansvaret og hvordan dette bør gjøres, så har vi kommet et godt stykke videre. Utvikling av nye modeller for samhandling omkring optimal sekundærprofylaktisk behandling av pasienter med perifer karsykdom vil kunne informere videre beslutninger om beste praksis på dette området.

\section{Anne Karin Lindahl}

akl@nokc.no

Anne Karin Lindahl (f. 1960) er dr.med. og karkirurg og arbeider som avdelingsdirektør ved Nasjonalt kunnskapssenter for helsetjenesten.

\section{Oppgitte interessekonflikter: Ingen}

\section{Litteratur}

1. Dormandy JD, Heeck L, Vig S. The natural history of claudication: risk to life and limb. Semin Vasc Surg 1999; 12: 123-37.

2. Norgren L, Hiatt WR, Dormandy JA et al. Inter-society consensus for the management of peripheral arterial disease (TASC II). Eur J Vasc Endovasc Surg 2007: 33 (suppl 1): $1-75$

3. Hirsch AT, Haskal ZJ, Norman R et al. ACC/AHA 2005 Practice Guidelines for the management of patients with peripheral arterial disease. Circulation 2006; 113 : e463-e-465

4. Diagnosis and management of peripheral arterial disease. A national cinical guideline. Scottish Intercollegiate Guidelines Network October 2006. Edinburgh: NHS Quality Improvement Scotland, 2006. www.sign.ac.uk (sign 89.pdf) (20.10.2009)

5. Kundhal KK, Chin SL, Harrison L et al. Patterns of medical therapy in patients with peripheral artery disease in a tertiary care centre in Canada. Can J Cardiol 2007: 23: 357-61.

6. Svilaas A, Westheim A, Kristoffersen JE et al. Risikofaktorer og intervensjon ved hjerte- og karsykdommer i allmennpraksis. Tidsskr Nor Lægeforen 1996; 116 : 2562-5.

7. Francke A Smit MC deVeer AJ et al. Factors influencing the implementation of clinical guidelines for health care professionals: a systematic meta-review. BMC Medical Informatics and Decision Making 2008; 8: 38. www.biomedcentral.com/1472-6947/8/38: (19.10.2009).

8. Grimshaw JM, Thomas RE, MacLennan G et al. Effectiveness and efficiency of guideline dissemination and implementation strategies. Health Technol Assess 2004; 8: iii-iv, 1 - 72 .

9. Jamtvedt G, Young JM, Kristoffersen DT et al. Does telling people what they have been doing change what they do? A systematic review of the effects of audit and feedback. Qual Saf Health Care 2006: 15: 433-6.

10. Norsk karkirurgisk forening. www. karkirurgi.org (13.10.2009) 